\title{
In Situ Resource Recovery from Waste Repositories: Exploring the Potential for Mobilization and Capture of Metals from Anthropogenic Ores
}

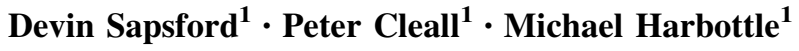

Published online: 5 December 2016

(C) The Author(s) 2016. This article is published with open access at Springerlink.com

\begin{abstract}
Wastes and the waste repositories in which they reside are becoming targets for resource recovery, both for legacy wastes and for future waste arisings as part of a desire to move toward a circular economy. There is an urgent requirement to explore concepts for practicable technologies that can be applied to these ends. This paper presents a synthesis of concepts concerning in situ technologies (developed from mining and contaminated land remediation industries) that have enormous potential for application to technospheric mining. Furthermore, potential target waste streams and their mineralogy and character are presented along with a discussion concerning lixiviant and metal capture systems that could be applied. Issues of preferential flow (critical to the success of in situ techniques) and how to control it with engineering measures are discussed in detail. It is clear that in situ recovery of metals from anthropogenic ores is a novel technology area that links new sustainable remediation approaches for contaminated materials and technospheric mining for closing material loops, and warrants the further research and development of technologies applicable to major waste streams.
\end{abstract}

Keywords Leaching - Mining - Industrial residues · Recycling $\cdot$ Technosphere $\cdot$ Remediation

The contributing editor for this article was Peter (Tom) Jones.

Devin Sapsford

SapsfordDJ@cf.ac.uk

1 Cardiff School of Engineering, Cardiff University, Cardiff, UK

\section{Introduction}

Waste repositories can be considered the ore deposits of the 'anthropocene.' Having historically disposed of vast quantities of industrial, municipal, metallurgical, and mining waste into or onto the ground, societies have put into geological storage an enormous quantity of resource in a range of materials of value such as metals and energy (in the form of biomass and polymers). Therefore, instead of considering these waste repositories to be a legacy waste issue and a long-term liability, a paradigm shift is required to view these installations as 'resource hubs' for future recovery. This has to some extent been recognized with commensurate but small-scale landfill mining occurring internationally [1], and the concept of mining materials from the 'technosphere' (rather than the lithosphere) is gaining ground. Following the definition of Johansson et al. [2], the 'technosphere' is defined as material stocks established by human agency, which originate from technological processes, in contrast to stocks in the lithosphere established by slow, primary geological processes. The technosphere can be distinguished from the lithosphere which is where historically humans have derived all of our metal resources. Of particular relevance, three major technospheric stocks have already been defined as 'controlled inactive stock' [2]: metals tailings, slag heaps (e.g., metallurgical wastes), and landfills, which are amenable to 'landfill' or 'secondary' mining.

The recovery of resources from waste repositories has not been widely adopted, beyond the limited extraction of landfill gas for energy generation. Attention is now turning toward recovering elements of value, for example, the so-called "E-tech" elements (Co, Te, Se, Nd, In, Ga, heavy rare earth elements) whose security of supply is an issue in addition to them being essential for current and future 
green technologies. Furthermore, there are the 'EU-20' supply-threatened critical materials including platinum group metals ( $\mathrm{Pt}, \mathrm{Ru}, \mathrm{Rh}, \mathrm{Os}$, and $\mathrm{Ir})$ and precious and base metals: $\mathrm{Au}, \mathrm{Pd}, \mathrm{Ag}, \mathrm{Cu}, \mathrm{Pb}, \mathrm{Zn}, \mathrm{Co}, \mathrm{Ni}, \mathrm{Sn}$, and Cr. Many of these elements are variously amenable to leaching (depending upon mineralogy) and found in significant concentrations in common wastes (e.g., tailings, metallurgical wastes, incineration ashes) but not in sufficiently high concentration to justify conventional ex situ processing. Additionally, there are predicted shortages in geological reserves for many metals, and exploitation of more complex deposits including anthropogenic deposits is a natural extension of this developing trend. There is also a clear synergy with the aims of a circular economy in returning as much resource as possible back into the production cycle. While recycling of metal goods is commonplace, metalbearing industrial residues have received less attention despite constituting a considerable resource, although metal recovery processes do exist for certain residues such as $\mathrm{FeCr}$ slags and municipal solid waste (MSW) incineration ashes.

In order to successfully and sustainably mine technospheric stocks, new technologies and/or those adapted from existing mining or remediation technology are required. As such, this paper aims to provide an overview of in situ resource recovery within a conceptual framework that seeks to (i) explain why in situ resource recovery technologies are appropriate to waste repositories; (ii) identify existing technologies that can be transferred to this new area; (iii) highlight key wastes/waste repositories that could be targeted; (iv) explain how the waste mineralogy will be critical in devising lixiviant systems; (v) discuss the issue of preferential flow and how to control it with engineering measures; (vi) identify metal capture technologies; and (vii) explore current technology development level, legislation, and international applicability.

\section{A Rationale for In Situ Recovery}

\section{Applicability of In Situ Recovery of Resources}

In situ techniques in mining include in situ leaching (ISL), dump leaching, and stope leaching. Heap leaching is not sensu stricto 'in situ' but 'ex situ.' However, since it is similarly low intensity and the leaching mechanisms applied would be the same, i.e., a stationary solid phase is flushed by an extractant (lixiviant), or the biogeochemical environment around the solid phase is manipulated in situ, here it is grouped with 'in situ' technology. This family of in situ techniques has been applied for the recovery of metals such as uranium, gold, silver, copper, and nickel and is applied to low-grade ores (for uranium ISL on grades as low as $0.05 \%$ ).

The use of in situ techniques in mining is prima facie for economic reasons. The cost of extraction of metals from ores (and contaminants from contaminated mixtures) is demonstrably inversely proportional to the concentration, fundamentally this is related to the thermodynamics of separation of chemical mixtures [3-5]. An increase in the exergy cost for extraction is imposed as the target becomes more dilute within the mixture. Valero et al. [5] express a unit exergy cost which is the ratio of the energy (real) cost of processes to remove target metals from ores to the exergy cost. Such analyses demonstrate that while the exergy cost of removing metals from low-grade ores increases dramatically as ore grade decreases, the commensurate unit exergy cost increase can be offset by more energy-efficient mining processes. This is reflected in the economics of ore processing and is why in situ processes, which keep energy costs to a minimum by negating the large energy requirements of conventional mining and processing (e.g., rock-moving, comminution, pyrometallurgy), are favored for low-grade ores.

Wastes, as is implicit in the use of the term, usually contain sub-economic concentrations of valuable resources (at least at the time of their production), and it should be recognized that this can vary with time. They can be considered as very low- to ultra-low-grade materials, and the detriment that this causes is twofold: (i) the economic incentive to process these materials becomes less and less; and (ii) the exergy cost increases as grade decreases. This is a critical point that is often overlooked in research on valorization of wastes. Overcoming the decreased exergy of metals in wastes, the increased energy to extract them and the consequent economic disincentive to recover metals is a key challenge. The extraction of resource may have other drivers in addition to the direct economic recovery of resource (e.g., remediation of impacts to environment and human health), which needs to be assessed in careful cost-benefit analyses, but it is clear that minimal processing costs will be advantageous and thus low-intensity (energy-wise) processes to remove metals are required. In situ techniques established in the mining industry and contaminated land remediation offer a promising avenue to explore.

\section{A Proposed Taxonomy for In Situ Techniques Applied for Resource Recovery}

Leaching in mining and removal of contaminants from contaminated land can be considered as reciprocal approaches: in land remediation, the aim is the recovery of the material (soil/sediment) with leaching, resulting in purification/decontamination of target soil, rather than in 
ore leaching where the target is the leached metal. However, these processes can be seen as being the same with simply a difference of perspective, where remediation recovers the soil material/value. The following taxonomy is proposed to clearly differentiate these two different aims when appraising the growing literature on in situ processes in resource recovery. Recovery can be subdivided into the following:

Direct recovery Recovery of resources from the waste repository while the waste remains in place, i.e., an efflux of the resource from the repository. Examples include the leaching and recovery of metals (as discussed herein) and methane capture and use from MSW landfills.

Indirect recovery This is the use of in situ decontamination or stabilization of the material in the waste repository to allow or facilitate the recovery of resources through subsequent exploitation, i.e., the focus is on the value recovered in the residue or the land rather than what is leached/removed. Thus, indirect recovery can be further subdivided into the following:

(i) Indirect Material Recovery through decontamination For example, Fedje et al. [6] discuss methods for leaching metals from MSW incineration fly ash so as to render the fly ash classifiable as nonhazardous waste-which facilitates reuse options.

(ii) Indirect Material Recovery through changing the physicochemical nature of the waste For example, the weathering/carbonation of blast furnace slags to remove problematic lime content ahead of its use as a product in aggregate applications and the accelerated carbonation of alkaline wastes, e.g., Van Gerven et al. [7].

(iii) Indirect Land Recovery The use of in situ decontamination or stabilization of the material in the waste repository to allow the recovery of land as a resource in itself. Examples include the range of in situ technologies in contaminated land remediation and waste stabilization.

Note that the process of recovering resource from waste repositories may involve a number of direct and indirect recovery technologies (e.g., Kim et al. [8]). In fact, the most desirable outcome for a waste repository might be a combination of direct and indirect recovery such that both the extracted resource and the residue are valorized. As such, in situ technologies both direct and indirect may contribute to the quest for zero-waste processes. The focus herein is on direct recovery of metals from wastes, while acknowledging that much of the presented information is also pertinent to indirect recovery.

\section{In Situ Technologies}

\section{Mining Technologies}

In situ leaching (ISL) involves accessing an ore deposit via a network of boreholes. The permeability may be enhanced through various stimulations, and then a lixiviant is pumped through the subsurface to solubilize the target metal which is then recovered at extraction bores. ISL has been used for the recovery of uranium, copper, nickel, zinc, cobalt, gold, and salt/trona. ISL has been most often applied to uranium leaching and accounts for a large proportion of uranium production. Acidic (sulfuric acid) or alkaline (ammonium or sodium bicarbonate/carbonate) lixiviant systems are typically used, although a much wider range of lixiviants are now being considered [9]. However, it is noteworthy that there have been many instances of poor environmental outcome from poorly/unmanaged uranium ISL operations [10].

Another important in situ technique applied at mine sites is dump leaching. This is where excavated materials are leached where they sit, contingent on the material sitting on a low-permeability base such that the leachate can be collected and metals removed. A variation of this is stope leaching, where the same process is conducted underground with piles of blasted low-grade ore. Furthermore, recirculation of water through the whole network of abandoned mine tunnels has also been practiced. As with ISL, clearly for in situ techniques the control and fate of the lixiviant is a vital issue for both process efficacy and environmental protection. It is feasible that a liner can be installed in situ through the use of grouts.

A more engineered version of dump and stope leaching is heap leaching. It involves the same principle but the material is crushed and stacked on an engineered liner system (either flat or in a valley-fill [11]) in order to capture all of the leachate which is applied with either sprinklers or emitters (drippers). Heaps can be 'multi-stack' where the material heap grows as progressive lifts are placed and leached, or 'dynamic' where materials are loaded and later unloaded from the pad. Dynamic pads might be useful where materials from a regional cluster of sites are to be processed. Where materials are fine-grained (as is common with many of the industrial and mining wastes considered here), then processing to agglomerate the materials prior to placing them on the heap leach pad is often undertaken to ensure sufficient permeability for leaching.

The metals are then extracted from the "pregnant" liquor which is collected from the base of the heap using approaches such as ion exchange/solvent extraction before 
electrowinning from the concentrated solution. Heap leaching is typically employed where ore grades are not sufficiently high to justify more intensive hydrometallurgical/pyrometallurgical options. This illustrates the continuum of options between process intensity (cost) versus recovery and rate of recovery and highlights that in situ techniques, as has been recognized by other authors (e.g., Steen and Borg [12]), are applicable for materials with lower concentrations. A summary of the mining technologies and their potential application to in situ recovery from waste repositories is presented in Table 1 .

Many commercial ISL, dump, and heap leaching operations involve bioleaching where sulfides are present. Metals bound as sulfides present an interesting case of a "self-extracting" system. Metals associated with sulfides, when exposed to the subaerial weathering environment, will be released as the sulfides spontaneously oxidize. The rate of weathering and release of metals from sulfides is kinetically controlled and influenced by microbes, including bacteria, archaea, and eukarya (see, for example, Schippers et al. [13]) with the ecosystem being driven by metabolic energy derived from the free energy available upon the oxidation of the ferrous and sulfur moiety of the sulfide minerals. This spontaneous breakdown of sulfide minerals is advantageous with regard to metal extraction (as is established with heap leaching of sulfide ores) but disadvantageous from an environmental perspective as it causes acid mine drainage and metal leaching from mines, which is one of the biggest causes of metal pollution worldwide. Therefore, wastes containing sulfides (e.g., mine tailings and mine wastes) will be amenable to selfextraction if engineered appropriately. Rather than trying to engineer mine waste repositories for isolation from oxygen/water ingress in perpetuity, allowing oxidation and leaching of metals from sulfides in an engineered and controlled fashion with metal capture and recovery might ultimately be a more sustainable approach to the long-term management of mining wastes.

\section{Contaminated Land Remediation Technologies}

A summary of the contaminated land technologies potentially applicable to in situ recovery from waste repositories is presented in Table 1. Both in situ and ex situ soil flushing have been investigated for the removal of metals from contaminated soils [14]. In situ recovery requires that the material to be flushed (as in the case of dump leaching in mining) overlies an impermeable stratum such that a pump-and-treat system can be applied to the soil capturing the extractant downstream in collection borehole(s) without polluting aquifers. A further variation of this approach is to excavate the material and place on a liner (as in heap leaching in mining), applying an extractant, collecting the pregnant liquor, removing the metals, and then recycling the extractant. Again, while this is technically ex situ, the nature of the leaching is in situ. Chelates are typically used to enhance metal removal, but while metal recoveries are dramatically improved with chelating agents, the metals are also then conversely difficult to extract from the chelates without resorting to expensive oxidation methods. Costs for the various contaminated land technologies range from a reported value of $10-228 € € / \mathrm{m}^{3}$ during 2001-2003 for in situ soil flushing to $22-222 € / \mathrm{m}^{3}$ for phytoremediation [15].

Phytoremediation is an established in situ technology (although still requires periodic harvesting) and is a very low-intensity 'land farming' technique for metal contamination remediation. Much recent research has been directed at chelate-enhanced phytoremediation (especially biodegradable chelates) to overcome the fact that many metals are not readily available for plants and/or have no natural tendency to hyperaccumulate in any plant species. Desirable plant species are those that are fast-growing, have a high biomass, and can be easily harvested [14]. Reported costs are scarce in the literature but a cost of $50-200$ US $\$ / \mathrm{m}^{3}$ is reported by Virkutyte et al. [16] for various methods applied in the 1990s. More recently, there has been interest in applying phytoremediation for Direct Recovery, this is called 'phytomining' (or agromining) and the estimated profitability of $\mathrm{Ni}$ phytomining using Berkheya coddii on serpentine soils rich in Ni (Australia) has been recently estimated at 11,500 AU\$/ha/yield and the profitability of Au phytomining using Brassica juncea is about 26,000 AU\$/ha/yield [17].

Electrokinetic (EK) techniques use the migration of suspended charged particles and chemical species under an applied electric field (known as electromigration) to remove metals from the subsurface. It is particularly applicable in fine-grained material, as it is not limited by low hydraulic conductivity. Indeed, the generation of electroosmotic water flow in fine-grained materials with an appreciable surface charge can aid in mobilizing contaminants. Typically, the process involves significant $\mathrm{pH}$ change within the treated material due to electrolysis of water at the electrodes, while the generation of a strongly acidic $\mathrm{pH}$ near the anode can mobilize metals and aid their recovery. The strongly alkaline environment near the cathode, to which most metals are attracted, can hinder recovery and so must be addressed. There is also an associated energy cost, as significant voltage gradients (typically $100 \mathrm{~V} \mathrm{~m}^{-1}$ ) are often required, but this is comparable to other interventions. It is therefore likely to be a feasible option for flow generation and control in wastes. EK techniques have been widely explored in the laboratory, and to a degree in field applications for removal of contamination, delivery of chemicals (e.g., electron 
Table 1 Existing technologies that have potential for application to in situ recovery of metals from waste repositories

\begin{tabular}{|c|c|c|c|c|c|}
\hline Technology & Target/application & Process inputs & Advantages & Limitations/constraints & Technology status \\
\hline In situ leaching (ISL) & $\begin{array}{l}\text { Ore bodies, } \\
\mathrm{Cu}, \mathrm{Au}, \mathrm{Ni}, \mathrm{Sc}, \mathrm{Re}, \\
\mathrm{REES}, \mathrm{Y}, \mathrm{Se}, \mathrm{Mo}, \\
\text { and V [9] }\end{array}$ & $\begin{array}{l}\text { Lixiviant addition } \\
\text { required, e.g., } \\
\text { sulphuric acid, } \\
\text { sodium } \\
\text { bicarbonate }\end{array}$ & $\begin{array}{l}\text { Lower capital } \\
\text { costs than } \\
\text { conventional } \\
\text { mining } \\
\text { Environmental } \\
\text { impacts (if } \\
\text { process is well } \\
\text { managed) are } \\
\text { lower than } \\
\text { conventional } \\
\text { mining }\end{array}$ & $\begin{array}{l}\text { Requires reasonable } \\
\text { permeability of } \\
1-5 \mathrm{~m} / \mathrm{d} \text { (natural or } \\
\text { artificial enhanced) } \\
\text { Targeted species may } \\
\text { be occluded within } \\
\text { rock inaccessible to } \\
\text { lixiviant } \\
\text { Not all material } \\
\text { contacted by } \\
\text { lixiviant leading to } \\
\text { incomplete leaching/ } \\
\text { recovery } \\
\text { Thicknesses and } \\
\text { grades, distribution } \\
\text { of mineralization, } \\
\text { requires presence of } \\
\text { aquicludes [9] } \\
\text { Environmental } \\
\text { concerns regarding } \\
\text { fate of lixiviant in } \\
\text { the subsurface }\end{array}$ & $\begin{array}{l}\text { First used for U } \\
\text { extraction in } \\
\text { 1959. Has been } \\
\text { used } \\
\text { extensively. } \\
\text { Future } \\
\text { expansion in use } \\
\text { predicted [9] }\end{array}$ \\
\hline Dump leaching & $\begin{array}{l}\text { Historically used to } \\
\text { recover metals from } \\
\text { surface dumps, } \\
\text { underground dumps } \\
\text { (stope leaching) and } \\
\text { underground mine } \\
\text { workings for } \mathrm{Cu} \text { and } \\
\mathrm{U}\end{array}$ & $\begin{array}{l}\text { Lixiviant addition, } \\
\text { e.g., sulphuric } \\
\text { acid, sodium } \\
\text { bicarbonate }\end{array}$ & $\begin{array}{l}\text { Lower capital } \\
\text { costs than } \\
\text { conventional } \\
\text { mining } \\
\text { Ease of } \\
\text { implementation } \\
\text { Can utilize mine } \\
\text { workings as } \\
\text { drainage } \\
\text { conduits }\end{array}$ & $\begin{array}{l}\text { Only permissable on } \\
\text { prepared sites } \\
\text { Leachability of target } \\
\text { depends on } \\
\text { liberation } \\
\text { Not all material } \\
\text { contacted by } \\
\text { lixiviant leading to } \\
\text { incomplete leaching/ } \\
\text { recovery } \\
\text { Environmental } \\
\text { concerns regarding } \\
\text { fate of lixiviant }\end{array}$ & $\begin{array}{l}\text { Discontinued on } \\
\text { unprepared sites }\end{array}$ \\
\hline Heap leaching & $\mathrm{Cu}, \mathrm{U}, \mathrm{Au}, \mathrm{Ag}, \mathrm{Ni}$ & $\begin{array}{l}\text { Lixiviant addition } \\
\text { required, e.g., } \\
\text { sulphuric acid, } \\
\text { sodium } \\
\text { bicarbonate, } \\
\text { cyanide }\end{array}$ & $\begin{array}{l}\text { Controlled } \\
\text { leaching on } \\
\text { engineered } \\
\text { liner, limits } \\
\text { escapes to } \\
\text { environment } \\
\text { Economic } \\
\text { extraction from } \\
\text { low-grade ores } \\
\text { possible }\end{array}$ & $\begin{array}{l}\text { Leaching time can } \\
\text { take several years } \\
\text { Leachability of target } \\
\text { depends on } \\
\text { liberation } \\
\text { Not all material } \\
\text { contacted by } \\
\text { lixiviant leading to } \\
\text { incomplete leaching/ } \\
\text { recovery } \\
\text { Capital costs of liner } \\
\text { and material } \\
\text { handling to load } \\
\text { leach pad } \\
\text { Fine-grained materials } \\
\text { require } \\
\text { agglomeration to } \\
\text { ensure good contact } \\
\text { with lixiviant }\end{array}$ & $\begin{array}{l}\text { First gold heap } \\
\text { leaching with } \\
\text { cyanide } \\
\text { 1900-1920s } \\
\text { [11] } \\
\text { Extensively used } \\
\text { for uranium, } \\
\text { gold and copper }\end{array}$ \\
\hline
\end{tabular}


Table 1 continued

\begin{tabular}{|c|c|c|c|c|c|}
\hline Technology & Target/application & Process inputs & Advantages & Limitations/constraints & Technology status \\
\hline Soil flushing & $\begin{array}{l}\text { Any contaminated } \\
\text { soils/sediment, } \\
\text { though availability } \\
\text { for transport is } \\
\text { critical }\end{array}$ & $\begin{array}{l}\text { Depending on } \\
\text { situation-range } \\
\text { of extractant } \\
\text { solutions } \\
\text { including } \\
\text { chelators, } \\
\text { surfactants, acids }\end{array}$ & $\begin{array}{l}\text { Low cost } \\
\text { compared to } \\
\text { comparable } \\
\text { methods such } \\
\text { as in vessel soil } \\
\text { washing }\end{array}$ & $\begin{array}{l}\text { Leachability of target } \\
\text { depends on solubility } \\
\text { and/or degree of } \\
\text { sorption. Highly } \\
\text { sorbed materials will } \\
\text { only slowly be } \\
\text { removed, though this } \\
\text { may be enhanced } \\
\text { with chelators and } \\
\text { other additives } \\
\text { Not all material } \\
\text { contacted by } \\
\text { lixiviant leading to } \\
\text { incomplete leaching } \\
\text { Environmental } \\
\text { concerns regarding } \\
\text { fate of extractant in } \\
\text { in situ soil flushing }\end{array}$ & $\begin{array}{l}\text { Developing } \\
\text { technology, not } \\
\text { extensively } \\
\text { applied }\end{array}$ \\
\hline Phytoremediation/phytomining & $\begin{array}{l}\text { Any-appropriate } \\
\text { plant selection may } \\
\text { tackle a wide range } \\
\text { of specific metals, } \\
\text { though availability } \\
\text { of resource is } \\
\text { critical } \\
\text { For phytomining Au, } \\
\text { Tl, Co, and Ni are } \\
\text { considered most } \\
\text { likely targets [17] }\end{array}$ & $\begin{array}{l}\text { Planting (low cost), } \\
\text { may need } \\
\text { continued care } \\
\text { and will require } \\
\text { harvesting } \\
\text { though this may } \\
\text { provide benefits } \\
\text { Often requires } \\
\text { chelating agents, } \\
\text { e.g., ethylene } \\
\text { diamine } \\
\text { tetraacetic acid } \\
\text { (EDTA) to be } \\
\text { used in } \\
\text { conjunction with } \\
\text { plant action }\end{array}$ & $\begin{array}{l}\text { Non-invasive } \\
\text { method } \\
\text { Low cost relative } \\
\text { to most other } \\
\text { techniques }\end{array}$ & $\begin{array}{l}\text { Low intensity-long } \\
\text { period of time } \\
\text { required } \\
\text { Biomass requires non- } \\
\text { straightforward } \\
\text { processing for metals } \\
\text { recovery } \\
\text { Low efficiency. } \\
\text { Recovery limited by } \\
\text { root distribution and } \\
\text { depth; phytotoxic } \\
\text { metal build-up may } \\
\text { adversely affect } \\
\text { plant; plants may not } \\
\text { tolerate more than } \\
\text { one or two specific } \\
\text { metals, limiting } \\
\text { applicability in } \\
\text { mixed wastes } \\
\text { Dependence on the } \\
\text { soil acidity, seasonal } \\
\text { and climatic } \\
\text { conditions }\end{array}$ & $\begin{array}{l}\text { Phytoremediation } \\
\text { has had some } \\
\text { commercial } \\
\text { application but } \\
\text { is uncommon } \\
\text { Phytomining } \\
\text { expected to be } \\
\text { commercial in } \\
\text { near future in } \\
\text { combination } \\
\text { with production } \\
\text { of biofuel [17] }\end{array}$ \\
\hline Electrokinetics & $\begin{array}{l}\text { Any, though limited } \\
\text { to electrically } \\
\text { charged materials } \\
\text { (particularly ions) } \\
\text { for rapid recovery. } \\
\text { Availability of } \\
\text { resource for } \\
\text { transport is critical }\end{array}$ & $\begin{array}{l}\text { Power supply } \\
\text { (typically } 100 \mathrm{~V} / \\
\text { m separation of } \\
\text { electrodes) } \\
\text { May need to be } \\
\text { coupled with an } \\
\text { extractant/ } \\
\text { lixiviant if target } \\
\text { is not dissolved }\end{array}$ & $\begin{array}{l}\text { Can be applied } \\
\text { successfully to } \\
\text { very fine- } \\
\text { grained } \\
\text { materials with } \\
\text { low hydraulic } \\
\text { conductivity }\end{array}$ & $\begin{array}{l}\text { Energy intensive } \\
\text { Electroosmotic flow } \\
\text { limited to } \\
\text { particulates with } \\
\text { high surface charge } \\
\text { Unlikely to work } \\
\text { where large metal } \\
\text { objects present (e.g., } \\
\text { municipal waste) }\end{array}$ & $\begin{array}{l}\text { Applied but not } \\
\text { mainstream } \\
\text { technique }\end{array}$ \\
\hline
\end{tabular}

acceptors to enhance bioremediation), and also dewatering of soils [18-21]. There is a good level of experience on the application of EK techniques in soils, but only limited consideration in wastes (e.g., Pedersen et al. [22]).
Practically, the technique has previously been implemented at relatively shallow depths for removal of contamination, but there do not appear to be significant barriers to operation at greater depth. 


\section{Candidate Wastes and Waste Repositories}

\section{Candidate Rationale}

The candidate materials generally fall under the classification of "controlled inactive stocks" [2] and are usually the result of current waste management practices. The following are candidate wastes which may be amenable to in situ recovery of metals. This consideration is based on the following reasoning: (i) there are extremely large mass arisings of these wastes; (ii) there are significant concentrations of metals of interest in them or that the matrix (once decontaminated) is valuable; (iii) there is evidence of hydrometallurgical research work being done on recovering metals from these materials (see Table 2); and (iv) they have suitable physicochemical characteristics (e.g., mineralogy, particle size, etc.). It is not an exhaustive list but highlights some of the key arisings which may suit in situ leaching. Furthermore, in all cases the recovery of land may be an important driver in progressing with mining of the wastes. Another key criterion for in situ techniques is hydraulic conductivity conducive to the flow of leachates. Many of the wastes do not meet this criterion but agglomeration and the use of EK are potential existing technological solutions.

\section{Ore Processing Residues}

Pyrometallurgical and hydrometallurgical processing of ores leads to a variety of wastes. Notable candidates for leaching are red mud, zinc refinery solid waste, and phosphogypsum. Research and development (and commercial recovery) is already underway for some types of ore processing residue, such as fayalitic slags, originating from processing of $\mathrm{Co}$ and $\mathrm{Cu}$ ores. Red mud is a waste arising from the Bayer process, the process by which aluminum is produced from bauxite ore. For every tonne of alumina produced, between 1 and 2 tonnes (dry weight) of red mud residues are produced [23]. The global annual arisings are 120 million tonnes and 2.7 billion tonnes of this material has been stockpiled [24]. It is composed primarily of fine particles of silica and aluminum, iron, calcium, and titanium oxides and hydroxides. Due to its high sodium hydroxide content, elevated $\mathrm{pH}$, and metal(loid) content (Al, As, Cr, Cu, Ni, Mo, V, and Zn) [25], red mud is viewed as hazardous waste. These elements might also be considered a resource, and red mud also contains rare earth elements (REEs) and scandium [26, 27].

Zinc refinery solid wastes are iron mineral-rich, often acidic, sludge residues from various processing routes of zinc ores. Ju et al. [28] estimate at least 1 million tonnes per annum of residue arising in China alone, containing $\mathrm{Zn}$,
$\mathrm{Pb}, \mathrm{Ag}, \mathrm{Cd}, \mathrm{Cu}, \mathrm{Ni}$, and In in a matrix of jarosite with zinc ferrite and anglesite. Various secondary process routes have been developed for recovery of valuable components from such residues, e.g., $\mathrm{Zn}, \mathrm{Ge}$, and In recovery [29], Zn and $\mathrm{Ga}$ [30], and $\mathrm{Pb}$ and $\mathrm{Ag}$ [31].

Phosphogypsum is the main waste product of the production of phosphoric acid by sulphuric acid digestion of a concentrated slurry of pulverized phosphate ores [32]. Phosphate ores are often naturally enriched in REEs, which report significantly to the process residues and can be recovered with acidic leaching (e.g., Preston et al. [33]). Example figures for REE content are given by Binnemans et al. [34].

\section{Coal Fly Ash and Bottom Ash}

While the UK usage of coal for power generation is rapidly decreasing as old coal-fired power stations are decommissioned and not replaced, the global consumption of coal for power has, for various economic reasons, actually increased and as such coal will likely continue to play a role in the global energy mix for many years. Waste arisings from coal combustion, principally fly ash and furnace bottom ash, have been variously utilized in applications such as a cement component in concrete, grout, and road bases but supply outstrips demand with only $25 \%$ being utilized globally [35, 36] and the remainder is stockpiled. Example figures for the EU arisings of coal combustion for energy generation residues for 2010 were $100 \mathrm{Mt}$ [37]. Arisings are circa $6 \mathrm{Mt}$ per annum in the UK alone, of which approximately $50 \%$ are utilized and an estimated $53 \mathrm{Mt}$ of fly ash lies in the UK repositories [38]. It is recognized that there is a pressing need for more applications [39] but most actual applications and research publications concern fly ash utilization in civil engineering applications. In terms of resource recovery, coal fly ash contains REEs [40] and there has been interest in coal ash as a resource of REEs (e.g., Franus et al. [41]), especially $\mathrm{La}, \mathrm{Ce}$, and Y. There has also been interest in the leaching of aluminum from coal ash [42]. There may also be potential for in situ recovery of potentially contaminating species such as $\mathrm{Cr}(\mathrm{VI}), \mathrm{V}$, and B where they occur at high enough concentrations to hinder ex situ reuse (particularly in unbound forms).

\section{Mine Wastes}

With annual extraction of ores and coal running to billions of tonnes, there is a commensurate and large production of mining wastes. Typical mine wastes include piles of overburden, waste rock, marginal ore, and tailings and mine water treatment sludges. In addition to these stocks, mine wastes (overburden and sub-ore stockpiles) form 
Table 2 Examples of studies concerning leaching of wastes and challenges in their potential application to in situ direct recovery from repositories

\begin{tabular}{|c|c|c|c|c|c|c|}
\hline \multirow{2}{*}{$\begin{array}{l}\text { Waste/ } \\
\text { repository }\end{array}$} & \multirow[t]{2}{*}{ Mineralogy } & \multirow[t]{2}{*}{ Amount } & \multirow{2}{*}{$\begin{array}{l}\text { Challenges for in situ } \\
\text { applications }\end{array}$} & \multicolumn{3}{|c|}{ Example leaching systems } \\
\hline & & & & Reference & Leaching target & $\begin{array}{l}\text { Lixiviant (optimum } \\
\text { conditions) }\end{array}$ \\
\hline \multirow[t]{6}{*}{ Red mud } & \multirow{6}{*}{$\begin{array}{l}\text { Hematite, } \\
\text { goethite, } \\
\text { boehmite, } \\
\text { quartz, } \\
\text { sodalite, } \\
\text { anatase and } \\
\text { gypsum [83] } \\
\text { Minor } \\
\text { presence of } \\
\text { calcite, } \\
\text { whewellite } \\
\text { and gibbsite }\end{array}$} & \multirow[t]{6}{*}{$\begin{array}{l}2.7 \text { billion } \\
\text { tonnes } \\
\text { globally }\end{array}$} & \multirow{4}{*}{$\begin{array}{l}\text { Average particle size } \\
<100 \mu \mathrm{m}) \text { is not } \\
\text { conducive to flow, } \\
\text { permeability would have } \\
\text { to be enhanced by } \\
\text { agglomeration } \\
\text { pretreatment or } \\
\text { electrokinetics } \\
\text { Lixiviant strength not } \\
\text { conducive to } \\
\text { environmental } \\
\text { protection or cost }\end{array}$} & $\begin{array}{l}\text { Agatzini- } \\
\text { Leonardou } \\
\text { et al. [84] }\end{array}$ & $\mathrm{Ti}$ & $\begin{array}{l}\text { Sulphuric acid (6 N, temp } \\
60^{\circ} \mathrm{C}, 5 \% \text { S:L) }\end{array}$ \\
\hline & & & & $\begin{array}{l}\text { Ochsenkühn- } \\
\text { Petropulu } \\
\text { et al. [85] }\end{array}$ & Sc, Yt, REEs & $\begin{array}{l}\text { Dilute nitric acid } \\
\left(0.5 \mathrm{~mol} / \mathrm{L}, 25^{\circ} \mathrm{C}, 24 \mathrm{~h}\right. \\
\text { S:L of } 1: 50\end{array}$ \\
\hline & & & & \multirow{2}{*}{$\begin{array}{l}\text { Qu and Lian } \\
{[86]}\end{array}$} & \multirow{2}{*}{$\begin{array}{l}\text { REEs, radioactive } \\
\text { elements }\end{array}$} & \multirow{2}{*}{$\begin{array}{l}\text { Bioleaching with } \\
\text { organism isolated from } \\
\text { red mud (Penicillium } \\
\text { tricolor) two-step } \\
\text { process at } 10 \%(\mathrm{w} / \mathrm{v}) \\
\text { pulp density }\end{array}$} \\
\hline & & & & & & \\
\hline & & & $\begin{array}{l}\text { Elevated temperature not } \\
\text { practical }\end{array}$ & \multirow[t]{2}{*}{$\begin{array}{l}\text { Vachon et al. } \\
\text { [87] }\end{array}$} & \multirow[t]{2}{*}{$\mathrm{Al}$} & $\begin{array}{l}\text { Citric/oxalic/sulphuric } \\
\text { acids. pH 1.5, } 28^{\circ} \mathrm{C}, 1: 6\end{array}$ \\
\hline & & & $\begin{array}{l}\text { Leaching tends to } \\
\text { solubilize iron }\end{array}$ & & & $\begin{array}{l}\text { Thiobacilli cultures, } \\
5 \% \text { v/v red mud and } 1 \% \\
\text { w/v sulfur }\end{array}$ \\
\hline \multirow[t]{3}{*}{$\begin{array}{l}\text { Zinc refinery } \\
\text { residue }\end{array}$} & \multirow{3}{*}{$\begin{array}{l}\text { Jarosite-type: } \\
\text { jarosite, zinc } \\
\text { ferrite and } \\
\text { anglesite } \\
\text { Goethite-type: } \\
\text { goethite } \\
\text { (containing } \\
\text { higher conc } \\
\text { of In, Ge, } \\
\text { Ga) }\end{array}$} & \multirow{3}{*}{$\begin{array}{l}\text { Unknown but } \\
\text { at least tens } \\
\text { of millions } \\
\text { of tonnes } \\
\text { from } \\
\text { literature } \\
\text { anecdotes }\end{array}$} & \multirow{3}{*}{$\begin{array}{l}\text { Particle size }(<200 \mu \mathrm{m}) \text { in } \\
\text { not conducive to flow, } \\
\text { permeability would have } \\
\text { to be enhanced by } \\
\text { agglomeration } \\
\text { pretreatment or } \\
\text { electrokinetics }\end{array}$} & Li et al. [29] & $\mathrm{Zn}, \mathrm{In}, \mathrm{Ge}$ & $\begin{array}{l}\text { Sulfuric acid/potassium } \\
\text { permanganate stage for } \\
\text { Zn, sodium chlorate for } \\
\text { In, Ge }\end{array}$ \\
\hline & & & & $\begin{array}{l}\text { Raghavan } \\
\text { et al. [88] }\end{array}$ & $\mathrm{Pb}, \mathrm{Ag}$ & $\begin{array}{l}\text { Brine leach followed by } \\
\text { ppt with sodium sulfide }\end{array}$ \\
\hline & & & & $\begin{array}{l}\text { Farahmand } \\
\text { et al. [89] }\end{array}$ & $\mathrm{Zn}, \mathrm{Pb}$ & $\begin{array}{l}\text { Sulfuric acid leach for } \mathrm{Zn} \\
\text { (pH 2.5, pulp density: } \\
200 \mathrm{~g} / \mathrm{L} \text {, leaching time: } \\
60 \mathrm{~min} \text { and temperature: } \\
80{ }^{\circ} \mathrm{C} \text { ) followed by } \\
\text { brine leaching for } \mathrm{Pb}\end{array}$ \\
\hline \multirow[t]{2}{*}{ Phosphogypsum } & \multirow{2}{*}{$\begin{array}{l}\text { Gypsum or } \\
\text { calcium } \\
\text { sulfate } \\
\text { hemihydrate, } \\
\text { Minor silica, } \\
\text { fluoride and } \\
\text { unreacted } \\
\text { phosphate } \\
\text { rock }\end{array}$} & \multirow{2}{*}{$\begin{array}{l}\text { Unknown but } \\
\text { of the order } \\
\text { of billions } \\
\text { of tonnes } \\
\text { from } \\
\text { literature } \\
\text { anecdotes }\end{array}$} & \multirow[t]{2}{*}{$\begin{array}{l}\text { Recovery can lead to } \\
\text { dissolution of the } \\
\text { phosphogypsum lattice } \\
\text { [26] }\end{array}$} & Habashi [90] & REEs & $\begin{array}{l}\text { Ambient temperature with } \\
\text { a } 0.1-0.5 \mathrm{M} \text { H2SO4 } \\
\text { solution in a solid-to- } \\
\text { liquid ratio of } 1: 10\end{array}$ \\
\hline & & & & $\begin{array}{l}\text { Preston et al. } \\
\text { [33] }\end{array}$ & REEs & $\begin{array}{l}\text { 1.0 } \mathrm{M} \text { nitric acid and } \\
0.5 \mathrm{M} \text { calcium nitrate }\end{array}$ \\
\hline \multirow[t]{2}{*}{$\begin{array}{l}\text { Coal Fly ash } \\
\text { and bottom } \\
\text { ash }\end{array}$} & \multirow{2}{*}{$\begin{array}{l}\text { Mullite, } \\
\text { quartz, } \\
\text { anhydrite, } \\
\text { lime, } \\
\text { magnetite, } \\
\text { feldspar, } \\
\text { glass }\end{array}$} & \multirow{2}{*}{$\begin{array}{l}750 \text { Mt of } \\
\text { coal ash per } \\
\text { year } \\
\text { globally } \\
\text { [91] }\end{array}$} & \multirow{2}{*}{$\begin{array}{l}\text { Particle size ultrafine } \\
(<10 \mu \mathrm{m}) \text { is not } \\
\text { conducive to flow, } \\
\text { permeability would have } \\
\text { to be enhanced by } \\
\text { agglomeration } \\
\text { pretreatment or } \\
\text { electrokinetics. }\end{array}$} & $\begin{array}{l}\text { Seidel and } \\
\text { Zimmels } \\
\text { [42] }\end{array}$ & $\mathrm{Al}$ & $\begin{array}{l}\text { Sulfuric acid leaching for } \\
\text { up to } 12 \text { days }\end{array}$ \\
\hline & & & & $\begin{array}{l}\text { Moreno et al. } \\
\text { [92] }\end{array}$ & $\begin{array}{l}\text { Decontamination } \\
(\mathrm{As}, \mathrm{B}, \mathrm{Cd}, \mathrm{Cr}, \\
\mathrm{Mn}, \mathrm{Pb}, \mathrm{Se}, \mathrm{V})\end{array}$ & $\begin{array}{l}\text { Deionized water, upflow } \\
\text { leaching }\end{array}$ \\
\hline \multirow[t]{2}{*}{ Mine wastes } & \multirow[t]{2}{*}{$\begin{array}{l}\text { Highly } \\
\text { variable }\end{array}$} & \multirow[t]{2}{*}{ See text } & \multirow[t]{2}{*}{$\begin{array}{l}\text { Danger of exacerbating } \\
\text { pollution generation }\end{array}$} & $\begin{array}{l}\text { Bulaev et al. } \\
\text { [93] } \\
\text { Mulligan }\end{array}$ & $\begin{array}{l}\text { Metals from } \\
\text { flotation pyrite } \\
\text { tailings }(\mathrm{Zn}, \mathrm{Cu} \text {, }\end{array}$ & $\begin{array}{l}\text { Percolation leaching } \\
134 \text { days leading to bio- } \\
\text { oxidation }\end{array}$ \\
\hline & & & & $\begin{array}{l}\text { Mulligan } \\
\text { et al. [94] }\end{array}$ & $\begin{array}{c}\mathrm{Au}, \mathrm{Ag}) \\
\mathrm{Cu}, \mathrm{Zn}, \mathrm{Ni}\end{array}$ & $\begin{array}{l}\text { Bioleaching at } 20^{\circ} \mathrm{C} \text { with } \\
\text { A. niger }\end{array}$ \\
\hline
\end{tabular}


Table 2 continued

\begin{tabular}{|c|c|c|c|c|c|c|}
\hline \multirow{2}{*}{$\begin{array}{l}\text { Waste/ } \\
\text { repository }\end{array}$} & \multirow[t]{2}{*}{ Mineralogy } & \multirow[t]{2}{*}{ Amount } & \multirow{2}{*}{$\begin{array}{l}\text { Challenges for in situ } \\
\text { applications }\end{array}$} & \multicolumn{3}{|c|}{ Example leaching systems } \\
\hline & & & & Reference & Leaching target & $\begin{array}{l}\text { Lixiviant (optimum } \\
\text { conditions) }\end{array}$ \\
\hline $\begin{array}{l}\text { Steel-making } \\
\text { dusts }\end{array}$ & $\begin{array}{l}\text { Franklinite, } \\
\text { iron, wustite, } \\
\text { zincite, and } \\
\text { haematite }\end{array}$ & $\begin{array}{l}0.02 \mathrm{t} / \mathrm{t} \text { of } \\
\text { steel }\end{array}$ & $\begin{array}{l}\text { Fine particle size } \\
(<50 \mu \mathrm{m}) \text { not conducive } \\
\text { to flow, permeability } \\
\text { would have to be } \\
\text { enhanced by } \\
\text { agglomeration } \\
\text { pretreatment or } \\
\text { electrokinetics } \\
\text { Recalcitrant mineralogy } \\
\text { Leaching solubilizes Fe }\end{array}$ & $\begin{array}{l}\text { Raza et al. } \\
\text { [95] }\end{array}$ & $\mathrm{Zn}$ & $\begin{array}{l}\text { 0.816 M Sulfuric acid, } \\
\left(65{ }^{\circ} \mathrm{C} \text { temperature, }\right. \\
44-63 \mu \mathrm{m} \text { particle size, } \\
20 \mathrm{~mL} \mathrm{~g}^{-1} \text { liquid to } \\
\text { solid ratio }\end{array}$ \\
\hline $\begin{array}{l}\text { Dredged } \\
\text { Sediments }\end{array}$ & Variable & $\begin{array}{l}\text { See text for } \\
\text { figures }\end{array}$ & $\begin{array}{l}\text { Particle size fine } \\
(<50 \mu \mathrm{m}) \text { not conducive } \\
\text { to flow, permeability } \\
\text { would have to be } \\
\text { enhanced by } \\
\text { agglomeration } \\
\text { pretreatment or } \\
\text { electrokinetics }\end{array}$ & $\begin{array}{l}\text { Zeng et al. } \\
\text { [96] }\end{array}$ & $\begin{array}{l}\text { Decontamination } \\
(\mathrm{Cd}, \mathrm{Zn}, \mathrm{Cu}, \\
\mathrm{Pb})\end{array}$ & $\begin{array}{l}5 \text { days bioleaching with } \\
\text { A. niger followed by } \\
2 \mathrm{~g} / \mathrm{L} \text { peroxide leach }\end{array}$ \\
\hline Soils & Variable & Unknown & $\begin{array}{l}\text { Lixiviant strength not } \\
\text { conducive to } \\
\text { environmental } \\
\text { protection }\end{array}$ & $\begin{array}{l}\text { Fedje and } \\
\text { Strömvall } \\
{[97]}\end{array}$ & $\begin{array}{l}\text { Decontamination } \\
\text { and recovery of } \\
\mathrm{Cu}\end{array}$ & $\begin{array}{l}\text { Highly acidic process } \\
\text { wastewater (pH around } \\
0)\end{array}$ \\
\hline
\end{tabular}

another group which although excavated by human agency have not been further processed so straddle the technosphere/lithosphere resource definitions.

For materials that are excavated, the classification of the materials as 'waste' is contingent on factors such as the value of the target metals at the time, their ease of extraction from the materials and the extraction process used for the particular site. Thus, what at certain times is considered a 'waste' is at other times an 'ore.' Tailings are the waste resulting from the beneficiation of mined materials to produce an ore concentrate for further processing. The tailings are thus concentrated in gangue (non-economic) minerals, but no beneficiation process is completely efficient and technologies are variously effective at separating ore from gangue minerals, so that a proportion of the target metals will report to the tailings. It is also the case that historic beneficiation processes were typically less efficient, and with changes in metal prices and technology the remining of old tailings or other mine wastes has occurred. For example, historic $\mathrm{Pb}-\mathrm{Zn}$ mines in Wales (UK) were originally mined for $\mathrm{Pb}$ in the late 19th century and the $\mathrm{Zn}$ minerals were discarded; these wastes were later reworked for $\mathrm{Zn}$ when $\mathrm{Zn}$ prices rose in the early 20th century. There is therefore the possibility that metals that were not originally the target metals for mining, but have since become economically important (e.g., the EU critical metals), maybe be enriched in the waste and become the valuable target (e.g., Dehain and Fillipov [43]). In terms of physical characterization, mine wastes tend to have a larger and wider particle size distribution than tailings which are typically fine $(<60 \mu \mathrm{m})$, and thus hydraulic conductivity of the materials for in situ leaching is an important consideration.

\section{Steel-Making Dusts}

There are a range of wastes arising from the multitude of metallurgical processes and the potential exists to recover resources (e.g., Fe, $\mathrm{Zn}, \mathrm{Mo}$ ) from them with a range of hydro- and pyrometallurgical techniques. Wastes include slags, dusts, and sludges from metal finishing processes.

Steel-making dusts including blast furnace, basic oxygen steel (BOS), and electric arc furnace (EAF) dusts are considered here as they constitute a large metallurgical waste stream. The BOS process involves the introduction of oxygen into the crucible of molten pig iron in order to reduce its carbon content. This creates waste dust up to $0.02 \mathrm{t} / \mathrm{t}$ of steel. These dusts cannot be recycled into the steel-making process for the iron content because of the presence of $\mathrm{Zn}$ (circa 10\%) [44] as a contaminant which has an adverse effect on the process performance and eventual quality of steel [45]. $\mathrm{Zn}$ is present because galvanized scrap is often used as an additional charge to the process and the $\mathrm{Zn}$ is volatilized into the furnace off-gas 
where it cools and forms zinc oxides and zinc ferrites (e.g., franklinite) in the dusts. The $\mathrm{Zn}$ in the dusts is amenable to acidic hydrometallurgical extraction (e.g., Havlik et al. [46]) as well as pyrometallurgical extraction (e.g., Jaafar et al. [47]) but poor separation between $\mathrm{Fe}$ and $\mathrm{Zn}$ extraction means that further processing is often required. A major route for recycling scrap is the use of electric arc furnaces. EAF dusts from this process are also very rich in zinc $(>20 \%)$ with franklinite being a major phase in the dust. Manganese, cobalt, nickel, and chromium also occur isomorphously substituted for $\mathrm{Zn}$ in the franklinite. Fe is present (other than in franklinite) mostly as magnetite, $\mathrm{Fe}_{3} \mathrm{O}_{4}[48,49]$.

Metallurgical dusts are a more likely target than metallurgical slags from a mobilization/dissolution perspective-although the dusts are composed of recalcitrant $\mathrm{Fe}$ and $\mathrm{Zn}$ oxides; they have a very small particle size, and thus limitations of solubility are somewhat mitigated. Again, with this comes the penalty of the reduced hydraulic conductivity for an in situ leaching process.

\section{Dredged Sediments}

Annually, approximately 40 million wet tonnes of sediments are disposed of in approximately 150 licensed disposal sites around the coast of England [50]. It is estimated that there are 100-200 million cubic meters dredged per year in Europe alone [51]. The main reasons for dredging include navigation, maintenance of operational shipping depth, flood control, construction and reclamation, and mining for infill materials. Reuse options for dredged sediments include both conditioning of agricultural land and fill applications. However, a considerable proportion of dredged materials are contaminated, which precludes reuse in many (especially unbound) applications. Of the approximately 300 million $\mathrm{m}^{3}$ of sediments dredged to deepen harbors and shipping lanes in the US, 3-12 million $\mathrm{m}^{3}$ are considered highly contaminated [52]. Metal removal from contaminated sediments would have the dual role of recovering metals and potentially allowing reuse of the decontaminated sediment. Several studies have examined soil flushing and/or heap leaching for decontamination of dredgings, [52-56]. In one study, $62 \%$ of the metals were leached in a 120-day percolation leaching test [55]. Akcil et al. [51] summarize the multifarious approaches that have been applied to metal recovery from aquatic contaminated sediments.

\section{Landfill Soils}

Metals have not historically been a target for recovery from MSW leachates as the leachates do not contain economically recoverable amounts of metals. Kjeldsen et al. [57] report that leached metals may account for less than $0.02 \%$ of the total metals present. The majority of the metal mass resides within the landfill in largely insoluble metallic (i.e., zero-valent) components. While there is scope to increase this substantially, dissolution of these wastes to later upcycle back to the native metals might be excessively energy intensive compared to ex situ landfill mining and physical separation to recover the metals. Ex situ landfill mining is starting to become a serious proposition, and Krook et al. [1] point out that soils from landfills systems have been a major target of previous landfill mining efforts. Kaartinen et al. [58] suggest that the fine fraction of landfill may comprise soil materials used for, e.g., landfill intermediate covers and can account for up to $74 \%$ of the landfill mass. As such, the fate of the fine fraction may be crucial for the economics of a landfill mining project, having to re-landfill soils because they are contaminated would (at least in Europe where landfill taxes are common) render the landfill mining uneconomic. Landfill fines (fraction $<75 \mu \mathrm{m}$ ) have been found to contain up to $30 \%$ metals, and high concentrations of $\mathrm{Zn}, \mathrm{Cu}, \mathrm{Cr}$, and $\mathrm{Pb}$ in particular have been reported [59]. Soil flushing or EK (see above) could be a useful decontamination/metal recovery technique which may render this large amount of soil a higher value. Thus, in this instance, a leaching approach might be applicable to materials recovered post ex situ mining.

\section{Hydrometallurgical Considerations}

The success of in situ leaching as either a mining or remediation process depends on whether the component of interest can be (i) solubilized from the matrix in which it resides at a rate which gives a realistic timescale for the process and then (ii) transported out of the system to be recovered. The manifold considerations for the first step are well known within the field of hydrometallurgy and thus several universal hydrometallurgical concepts are important in any in situ leaching scenario.

The bulk solubility of wastes and the solubility of individual metals of interest in the lixiviant is dependent on the mineralogy, particle size, and crystallinity of the waste. The rate of recovery of metals will be contingent on the degree of liberation of metal-bearing minerals and their leaching kinetics. Wastes such as smelter slag, while metalrich, may be vitreous and practically insoluble in all but the most aggressive lixiviants and thus not suitable for in situ leaching. Other metals may be soluble but physically occluded within the interior of large particles, which restricts mass transfer to the dissolved phase. Where metals within wastes are not sufficiently soluble in water alone, a lixiviant can be selected, which significantly enhances 
solubility through $\mathrm{pH}$ change (e.g., sulphuric acid), redox manipulation, complexation/chelation, or by in situ conversion by reaction of the recalcitrant phase into a more water-soluble or environmentally reactive phase. This is where hydrometallurgical considerations for recovering metals from wastes come to the fore.

The choice of lixiviant will depend upon the deportment of metals within minerals comprising the waste and whether they can be solubilized by (bio)geochemical manipulation. Many existing heap leach processes use acid leaching (e.g., sulfuric acid in $\mathrm{Cu}$ and $\mathrm{Ni}$ recovery) or complexation (cyanide lixiviant for $\mathrm{Au} / \mathrm{Ag}$ recovery or $\mathrm{NaHCO}_{3}$ for uranium recovery). Chelation (multidentate complexation) has also been used extensively for treatment of contaminated soils. While ethylene diamine tetraacetic acid (EDTA) has been investigated (e.g., Sun et al. [60]), it is toxic and research into new biodegradable selective chelating agents is underway (e.g., Wu et al. [61]). There are also a range of microbially produced chelates that might be applied to enhance solubilization of target metals; for example, Acidithiobacillus thiooxidans and Aspergillus niger have been tested for application to the leaching of steel slag [62], while Cheng et al. [63] examined bioleaching from $\mathrm{Pb} / \mathrm{Zn}$ smelter slags. A recent and thorough review on bioleaching of solid waste and secondary resources was conducted by Lee and Pandey [64]. Table 2 shows examples of (bio)hydrometallurgical systems from the literature which might be useful for in situ leaching of candidate waste repositories.

\section{Control of Preferential Flow}

Lixiviant contact with the metal-bearing particles and transport of the solubilized components from the wastes is clearly key to successful leaching of metals. Therefore, the control of preferential flow within the waste mass itself is likely to be a critical and challenging issue for the success of in situ leaching as it is within the mining industry. The efficiency of leaching techniques can be significantly affected by preferential flow, which occurs in porous media as a consequence of non-idealities at a range of scales. Resistance to hydraulic flow through such media is affected by pore structure and properties such as throat size, volume, particle angularity and orientation, etc. This causes fluid flow to be non-uniform both at the microscopic scale and at the macroscopic scale due to features such as stratigraphy, lenses, and other structural features in soil deposits. In rocks, preferential flow is governed primarily by distribution, size, and orientation of fractures rather than the porosity of the rock itself. Preferential flow has caused issues in remediation of contaminated soils, where technologies such as pump and treat require uniform flow to remove all contamination [65], and in agriculture where the loss of pesticides and fertilizers occurs due to non-uniform flow, with consequent environmental impacts $[66,67]$.

Wastes are, to a greater or lesser extent, heterogeneous materials and some (municipal wastes in particular) also change with time due to degradative effects. As with all varied particulate materials, they are susceptible to preferential flow, and this flow may in some cases be temporally variable. The likely target wastes described in "Candidate Wastes and Waste Repositories" section are all particulate and will all exhibit heterogeneity at a range of scales depending on both the nature of the grains (including size, shape, material variability, and durability) as well as the nature of their introduction into, and their distribution in, the repository (including packing and compaction, spatial distribution, saturation, and flow of pore fluids). Heterogeneity is an inherent property of all particle arrangements unless perfect 'crystalline' structures, with identical packing, and orientation of particles, can be obtained throughout the waste mass-this is practically unattainable. Particles of wastes such as ore processing wastes, steel-making dusts, and ashes, whose nature depends on the parent material and the process to which it is subjected, may be relatively uniform unless the process parameters change during production, but even with these heterogeneity will always arise in their arrangement within the repository (microscopically and macroscopically), thereby causing preferential flow.

In situ technologies for recovery of resource from waste bodies require fluid flow through the waste, and to maximize recovery from all parts of the waste body is likely to require some form of flow control. Control of preferential flow is not common practically. There are, however, examples of technologies in the scientific literature that describe potential methods of control and these are discussed below.

\section{Hydraulic Flow Control and Non-idealities in Flow Processes}

When using leaching to recover materials, flow is usually applied to the system. The manner in which flow is applied may help avoid preferential flow. In highly stratified deposits, for example, macroscopic preferential flow may possibly be overcome by applying flow perpendicular to the deposit orientation although at smaller scales it is likely to still occur. Cote et al. [68] describe how flow interruption can increase solute leaching efficiency by up to $20 \%$ compared to continuous leaching. Drainage of main flow paths was also practiced between leaching events. The effect was attributed to equalization of concentrations in any undrained zones during the periods of flow cessation. Note that the efficiency of leaching may not be in terms of 
mass removal versus time, but in mass removal versus time of flow: efficiencies may therefore reduce overall operational costs but timescales may not be significantly affected.

Hydraulic flow controls are highly applicable and require little additional development. It is likely, however, that in practice it will prove more difficult to fully overcome preferential flow with such methods. It is not thought that the method has been applied in resource recovery, but has been considered in contaminated land remediation [68].

Where the particle sizes or ores are prohibitively small in terms of ensuring sufficient hydraulic conductivity for the lixiviant, then agglomeration techniques (using water and/or binders) have been applied to fines to improve lixiviant contact and flow in heap leaching, resulting in good recoveries even for fine-grained materials. However, agglomeration may not be feasible, particularly when using strictly in situ methods, and does not necessarily fully overcome the problem of preferential flow.

\section{Cut-off Walls and Permeation Grouting}

Many techniques for controlling groundwater borrowed from contaminated land control would be applicable for bulk control of groundwater/lixiviant flow during in situ applications. An excellent summary of these techniques is provided in LaGrega et al. [69], including circumferential and downgradient cut-off walls (keyed into an aquiclude), soil-bentonite and cement-bentonite slurry trench cut-off walls, plastic, concrete, diaphragm, and vibrating beam cut-off walls. Grout curtains as well as proposed horizontal barriers including grouted liners and lagoon sealing techniques are also considered. Furthermore, LaGrega et al. [69] describe pump and treat, drain tile collection systems (French drains), and biopolymer extraction/interception trenches used for the capture of contaminated groundwater, which are thus directly applicable in the collection of lixiviant in in situ leaching of waste repositories.

Injection of grout under pressure has been considered in the creation of impermeable barriers, for example underneath existing waste sites where vertical trench construction would not apply. Typically, this is only applied to coarse-grained soils (sands and gravels) where standard cement-based grouts are used but the use of ultrafine cements and other materials has allowed the use in finer materials. Alternative technologies such as using chemical grouts (where the reactants are entirely liquid or soluble) or jet grouting may extend this. In terms of use as a control of preferential flow, the technology has not previously been considered, as usually the aim is to make an entire soil mass impermeable. However, Dwyer [70] reports that heterogeneity in the finished product may be due to preferential flow of the injected material and therefore the use of the technique (for creating an impermeable barrier) should be limited to homogenous soils. It should be selfevident that flow will occur in preferential flow paths at least initially and so there is potential for this technology to be adapted for use in in situ mining.

\section{Bioclogging and Biomineralization}

Biofilms occur in soils, sediments, and many other environments and basically comprise large amounts of biopolymers exuded by microorganisms. When conditions allow, they can grow and extend, leading to clogging of pore space and flow diversion. Reductions in hydraulic conductivity of several orders of magnitude have been observed in soils [71], leading to diversion of fluid flow [72]. Biofilm has been considered as a hydraulic barrier to prevent escape of contamination via pore fluid transport [73]. In shorter term applications, biofilms have been shown to be successful in diverting flow, for example in microbially enhanced oil recovery (MEOR) where biofilm growth in preferential flow paths within oil reservoirs diverts fluid flow and increases recoveries of oil by flushing [74]. The ability of biofilm growth to control and divert groundwater flow in heterogeneous aquifer materials is being explored for contaminant remediation in soils (Alshiblawi and Harbottle, unpublished results), showing that water flow of water can be diverted through less permeable paths due to bioclogging of the preferential flow paths.

A number of bacterial species have the capability to generate minerals (biomineralization). The mechanisms involved are varied and result in a range of mineral types, such as carbonates, sulfides, and others. A common mechanism is calcite generation instigated by urea hydrolysis, which leads to an increase in carbonate ion concentration alongside an elevated $\mathrm{pH}$. The production of such minerals in porous media reduces pore space, resulting in similar effects to those noted with biofilm-significant reductions in hydraulic conductivity have been noted [75].

\section{Electrokinetic Methods}

Application of electrokinetics (see "Contaminated Land Remediation Technologies" section) can overcome heterogeneity within the target media because it does not rely on hydraulic flow to bring about recovery or remediation. Flow of the electrical current occurs equally well, or better, through fine-grained materials as it does in coarser fractions due to potentially greater electrical conductivity of the pore fluid in such materials. It may be, therefore, that it is still affected by heterogeneity in that better recovery may come from fine-grained regions of waste, but it is often the case that materials of interest are associated with 
the fines fraction [59], and so in this case heterogeneity may positively reinforce recovery. For similar reasons, the combination of electrokinetics techniques with hydraulic flow methods is likely to be necessary to bring about improved and sufficiently timely removal, with, for example, electrokinetic transport moving target metals out of fine-grained zones to preferential flow paths where they can quickly be removed using traditional hydraulic techniques.

\section{Applicability}

The techniques described in "Hydraulic Flow Control and Non-Idealities in Flow Processes" to "Bioclogging and Biomineralisation" sections directly control flow, and so could be coupled with any of the flow-based techniques described in "In situ technologies" section (any form of in situ leaching, as well as the very similar in situ and ex situ flushing). It would be necessary to ensure that the flow control method was compatible with the leaching method, however; particularly the lixiviants employed, as cementitious grouts, walls, and biomineralized materials such as carbonates in particular, are likely to be deleteriously affected by acidic lixiviants.

Electrokinetic methods for resource recovery essentially do away with the need for flow control either because the need for hydraulic flow is obviated entirely by relying on electrokinetic transport phenomena or because the electroosmotic flow is directly controlled by the electric field. Externally applied flow may not, therefore, be necessary. However, electrokinetic transport phenomena can be slow where distances extend beyond a few meters and so a combination of electrokinetic and flow-based techniques (as described in the preceding section) has considerable potential. Although not directly an issue of preferential flow, electrokinesis can enhance a number of resource recovery methods due to its highly controllable nature. Phytoremediation, for example, has previously been combined with electrokinetics to enhance the availability and rate of transport of contaminants to the rhizosphere, increasing the reach of the phytoremediation system [76].

\section{Process Intensity and Metal Capture}

\section{Process Deintensification}

Decisions on the intensity of the beneficiation process are based largely on economics related to the ore grade, mineralogy/metal deportment, and liberation. The same reasoning has been applied to the economics of remediation of contaminated land [77]. Because wastes are of ultra-low grade, lower intensity processing through in situ techniques is attractive. This leads to the question of how far should and how far can the reduction in process intensity be engineered. The ultimate recovery and the recovery rate of the target species are clearly important as to the ownership of the waste liability. If the incentive for the in situ leaching is economic recovery of metals through leaching (direct recovery) or decontamination of the material (indirect recovery), then the process necessarily has to be fast enough to ensure economic viability, while if the driver is decontamination of orphaned industrial legacy sites (albeit with economic recovery of metals to offset remediation), then the required intensity might be extremely low. It is possible to picture the opposite end-points of a spectrum of process intensity for resource recovery processes: with active ex situ mining and intensive beneficiation of a waste material at one end, and completely passive leaching of a waste by rainwater and capture of metals at the other end over decades.

\section{Metal Capture}

The intensity of processing also dictates the intensity of metal capture from the aqueous stream once metals have been mobilized and recovered from the waste. The decision about process intensity will be based (as discussed above) on the various cost/benefits which inform metal recovery and decontamination of wastes. Inevitably, factors such as less-intensive leaching systems using non-aggressive, environmentally benign lixiviants and limitation of recovery by heterogeneous flow mean that the intensity of in situ processing of wastes will be much lower and the timescales will possibly be counted in years. Thus, the technology used to capture the metals leached from the system has to be of commensurate intensity. For example, in high-value process-intensive systems such as gold processing, the gold is captured by 'carbon in pulp' and the carbon stripped from the gold, whereas lower intensity leaching systems might use ion exchange resins.

Low-intensity leaching needs commensurate metal capture techniques. Useful analogues are being developed for the "passive" treatment of metalliferous mine waters. Such systems use a variety of (bio)geochemical engineering approaches to achieve immobilization of metals. Various processes of adsorption, cementation, (bio)precipitation through microbiological reduction and/or oxidation, and manipulation of $\mathrm{pH}$ can achieve the sequestration of metals. Thus, these technologies offer readily transferable options for low-intensity harvesting of metals which achieve (i) eventual decontamination of the mine waste, (ii) protection of the environment from metal pollution, and (iii) recovery of the metals. This could also be viewed as engineering the formation of future anthropogenic mineral deposits. 


\section{Sustainable Remediation Context: Resource Recovery, Gentle Remediation, and Ecosystem Services}

An important consideration not taken into account in many cost/benefit calculations is ecosystem service benefits/disbenefits as well as landscape services related to sociocultural aspects of wastes which are important in some cases, e.g., historic mines. Many waste repositories provide ecosystem services with respect to wildlife habitat and can be among other things important educational and heritage features of the landscape. Thus, when considering recovery of metals from waste repositories, these factors need to be taken into account. The lower the intensity of the process, the lower the impact (probably) on potential ecosystem services that the site provides and thus lower intensity approaches to resource recovery may add (if apportioned significant weighting in the decision making) considerably to the benefits in the cost/benefit analysis. Parallels can be drawn from contaminated land risk management which has evolved from a focus on containment, cover, and removal to landfill through to in situ and ex situ treatment technologies and more recently to the concept of gentle remediation options where soil functionality is retained (and thus the ecosystem services of that soil preserved) in addition to risk management [77]. These technologies use plant, fungal, and microbiological methods, with or without chemical additives, for reducing contaminant transfer to local receptors by in situ stabilization or extraction of contaminants and are considered as part of a new suite of sustainable remediation technologies. In situ recovery of metals from waste repositories where the dual purpose of decontamination and site reclamation is achieved also fits into this classification.

\section{Toward Application}

\section{Technology Readiness Levels}

In recent years, Technology Readiness Levels (TRLs) have been adopted by policy makers, scientists, and engineers in a number of areas as a way of quantifying an estimate of the maturity of a particular process or technology. While various TRL definitions exist, most range from a TRL of 1 , where only the basic principles have been observed, to a TRL of 9, where the technology has been successfully applied in its operational environment. The TRLs adopted by the European Commission as part of its H2020 programme [78] are summarized in Fig. 1 alongside estimates of the current technological readiness of the various in situ technologies considered here. The estimates are based upon the assessment methodology adopted by Rybicka et al. [79] with an initial first-stage allocation where TRL 1-3 was defined as being at the laboratory scale, $4-6$ at the pilot scale, and 7-9 at the commercial scale followed by a second allocation to determine, where possible, a single TRL level.

It is acknowledged that these assessments are dependent on the authors' judgement and as such can only be classed as estimates. In some cases, the technologies are at different TRLs for different applications or in different environments. For example, bioclogging has been investigated for use in the recovery of oil from porous rock and in that context is close to actual proven implementation [80] so its TRL is perhaps $7-8$, but as in the context of resource recovery this is a very different environment, and its TRL for waste repositories is judged here as being at 3-4. Similarly, permeation grouting has been used extensively for other purposes, and so practical issues regarding its implementation have been overcome, but in different situations, the TRL is therefore judged here as 4. Furthermore, electrokinetic methods are well established in the field of remediation [81] but again not in the context resource recovery resulting in the TRL of 6 . It is clear that technologies derived from the mining sector are very close to full commercial implementation, as the environmental conditions are comparable, resulting in the TRLs of 8-9; however, a number of other technologies are a considerable way from even pilot-scale demonstrations.

\section{Legislation}

While national legislative structures vary, it is likely that there will be a number of legislative regimes that could potentially be applied when considering the application of in situ techniques for resource recovery. These regimes will largely be the consequence of legislation introduced to either regulate waste management practices, mineral resource extraction, or regulate the assessment and remediation of contaminated land. It seems reasonable to expect that this will initially be considered at a site-specific level, until a clear precedent has been set; for example, in the UK context this establishment of legal precedent is not an unusual process in planning and regulatory processes. Also as noted in Crane et al. [82] the European Union Water Framework Directive is likely to result in the requirement of more stringent pollution control-driven interventions, and in such cases in situ approaches may well be implemented to offset remediation cost.

\section{Future Research Directions}

There is much scope for the development of the in situ approach to technospheric mining, and fruitful avenues for future research include (i) in situ conversion of wastes to 


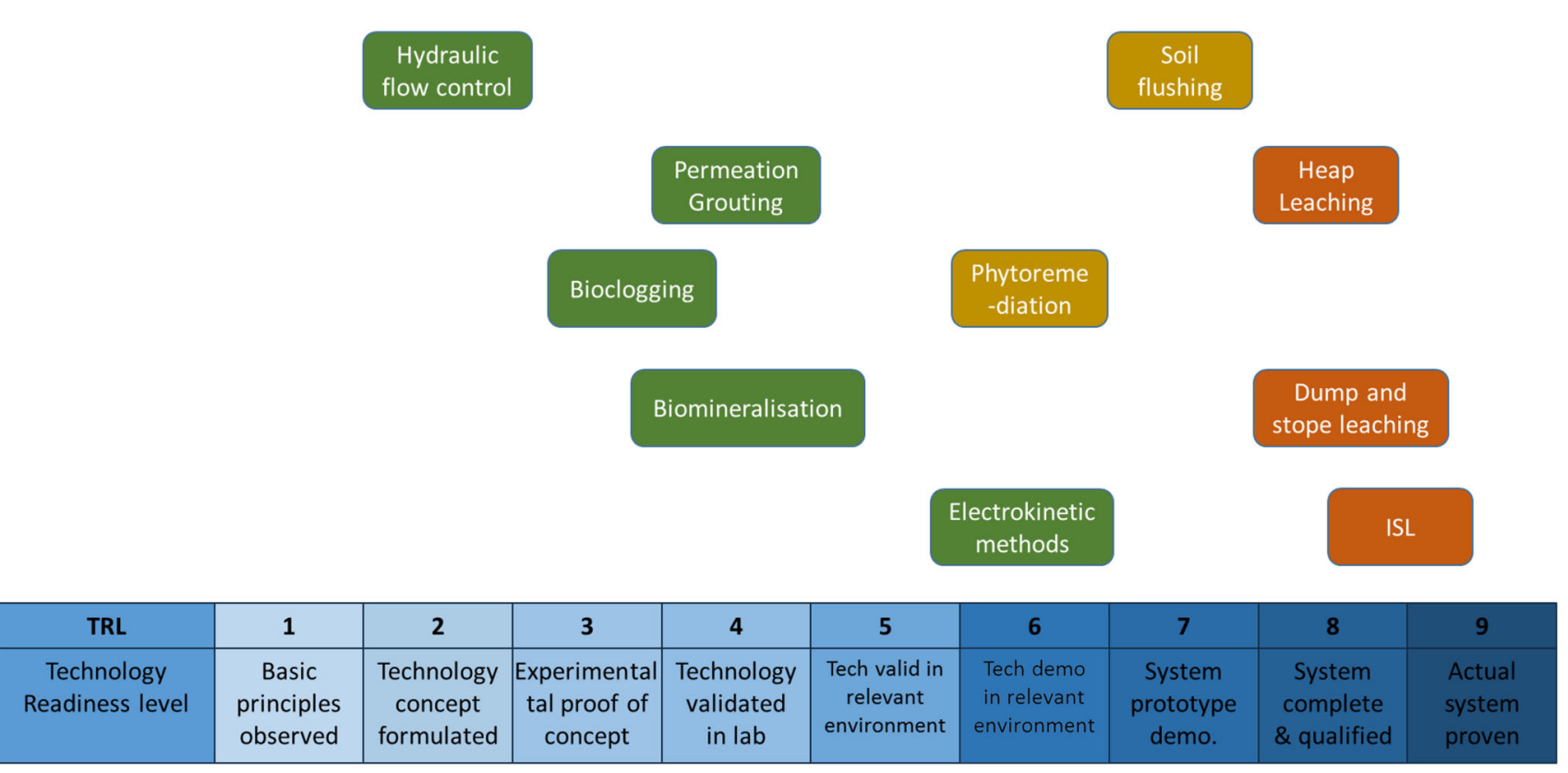

Fig. 1 Assessment of the TRL of technologies' applications to in situ recovery of resources from waste repositories

high-value products, (ii) the application of new metallurgical approaches that are highly selective to the target metals, (iii) novel technologies for the manipulation of biogeochemical environments within waste repositories to achieve dissolution of target species, and (iv) novel technologies for controlling flow in materials of low hydraulic conductivity.

\section{International Perspective}

Waste repositories are ubiquitous, both industrial and municipal, although the degree of engineering in such facilities varies significantly between countries and between waste types. In the UK, Europe, the US, and other areas where waste management is a mature industry, waste disposal in geological repositories is, in some cases, considered old-fashioned and there is a move away from such large-scale disposal of waste. An example is a shift toward greater incineration for municipal wastes. Resource recovery in these locations is therefore likely to focus on tackling residues from such processes alongside the largescale industrial waste sources. The consideration of wastes as 'leakage' from the circular economy will therefore have to be bolted onto an existing industry, with the challenges and inefficiency that will likely result. In other parts of the world where waste management industries are developing, there may be more scope to intervene and to encourage the inclusion of a circular economy approach from the beginning, allowing these industries to leapfrog the current state of play elsewhere. For example, through design of waste repositories as temporary, rather than final, storage, and allowing for low-intensity recovery processes, the concept of the circular economy may be thoroughly embedded within the waste management industry.

\section{Conclusions}

The in situ recovery of metals has been applied variously in mining and contaminated land environments although with different objectives. However, many aspects of both of the existing technologies are readily transferable to technospheric mining. This paper has outlined some of the key wastes where in situ leaching and related technologies could be applicable, outlined the similarities with existing processes and their geochemistry, and sought to outline the continuum of concepts between remediation and metal recovery and how this fits in with concepts of sustainable remediation. Future waste repositories from mining, metallurgical, and industrial wastes must be designed as "temporary storage" for future recovery of metal resources. Given the low grade of resources in typical wastes, these recovery techniques must necessarily be low intensity in terms of energy and reagent consumption. In situ recovery of metals involves mobilization, transport, and capture of the target metals in a concentrated form-the challenge is to devise various physical, chemical, biological, and biogeochemical engineering technologies to achieve this.

Acknowledgements This research was funded by the Natural Environment Research Council (NERC) Grant NE/L013908/1 "In situ recovery of resources from waste repositories." 


\section{Compliance with Ethical Standards}

Conflict of interest The authors declare that they have no conflict of interest.

Open Access This article is distributed under the terms of the Creative Commons Attribution 4.0 International License (http://crea tivecommons.org/licenses/by/4.0/), which permits unrestricted use, distribution, and reproduction in any medium, provided you give appropriate credit to the original author(s) and the source, provide a link to the Creative Commons license, and indicate if changes were made.

\section{References}

1. Krook J, Svensson N, Eklund M (2012) Landfill mining: a critical review of two decades of research. Waste Manag 32:513-520

2. Johansson N, Krook J, Eklund M et al (2013) An integrated review of concepts and initiatives for mining the technosphere: towards a new taxonomy. J Clean Prod 55:35-44

3. Gutowski TG (2011) Materials separation and recycling. In: Thermodynamics and the destruction of resources, Cambridge University Press, Cambridge, 113-132

4. Valero A, Dominguez A, Valero A (2015) Exergy cost allocation of by-products in the mining and metallurgical industry. Resour Conserv Recycl 102:128-142

5. Valero A, Valero A, Dominguez A (2011) Trends of exergy costs and ore grade in global mining. In: sustainable development in the minerals industry, Aachen

6. Fedje KK, Ekberg C, Skarnemark G et al (2012) Initial studies of the recovery of $\mathrm{Cu}$ from MSWI fly ash leachates using solvent extraction. Waste Manag Res 30:1072-1080

7. Van Gerven T, Van Keer E, Arickx S et al (2005) Carbonation of MSWI-bottom ash to decrease heavy metal leaching, in view of recycling. Waste Manag 25:291-300

8. Kim E, Spooren J, Broos K et al (2016) Valorization of stainless steel slag by selective chromium recovery and subsequent carbonation of the matrix material. J Clean Prod 117:221-228

9. Seredkin M, Zabolotsky A, Jeffress G (2016) In situ recovery, an alternative to conventional methods of mining: exploration, resource estimation, environmental issues, project evaluation and economics. Ore Geol Rev 79:500-514

10. Gavrilescu M, Pavel LV, Cretescu I (2009) Characterization and remediation of soils contaminated with uranium. J Hazard Mater $163: 475-510$

11. Zanbak C (2012) Heap leaching technique in mining within the context of best available techniques (BAT). Euromines-The European Association of Mining Industries, Metal Ores and Industrial Minerals

12. Steen B, Borg G (2002) An estimation of the cost of sustainable production of metal concentrates from the earth's crust. Ecol Econ 42:401-413

13. Schippers A, Breuker A, Blazejak A et al (2010) The biogeochemistry and microbiology of sulfidic mine waste and bioleaching dumps and heaps, and novel Fe(II)-oxidizing bacteria. Hydrometallurgy 104:342-350

14. Lestan D, Luo CL, Li XD (2008) The use of chelating agents in the remediation of metal-contaminated soils: a review. Environ Pollut 153:3-13

15. Summersgill M (2006) Remediation technology costs in the UK \& Europe; drivers and changes from 2001 to 2005. In: Thomas HR (ed) 5th International Congress on Environmental Geotechnics. Thomas Telford, Cardiff, 310-317
16. Virkutyte J, Sillanpaa M, Latostenmaa P (2002) Electrokinetic soil remediation: critical overview. Sci Total Environ 289:97-121

17. Mahar A, Wang P, Ali A et al (2016) Challenges and opportunities in the phytoremediation of heavy metals contaminated soils: a review. Ecotoxicol Environ Saf 126:111-121

18. Acar YB, Alshawabkeh AN (1993) Principles of Electrokinetic Remediation. Environ Sci Technol 27:2638-2647

19. Gill RT, Harbottle MJ, Smith JWN et al (2014) Electrokineticenhanced bioremediation of organic contaminants: a review of processes and environmental applications. Chemosphere 107:31-42

20. Harbottle M, Tomkinson W, Lewin G et al (2015) Electrokinetic biosparging of toluene in groundwater. Environ Geotech 2:26-33

21. Shang JQ (1997) Electrokinetic dewatering of clay slurries as engineered soil covers. Can Geotech J 34:78-86

22. Pedersen AJ, Ottosen LM, Villumsen A (2003) Electrodialytic removal of heavy metals from different fly ashes: influence of heavy metal speciation in the ashes. J Hazard Mater 100:65-78

23. Kumar S, Kumar R, Bandopadhyay A (2006) Innovative methodologies for the utilisation of wastes from metallurgical and allied industries. Resour Conserv Recycl 48:301-314

24. Klauber C, Grafe M, Power G (2011) Bauxite residue issues: II. options for residue utilization. Hydrometallurgy 108:11-32

25. Lockwood CL, Stewart DI, Mortimer RJG et al (2015) Leaching of copper and nickel in soil-water systems contaminated by bauxite residue (red mud) from Ajka, Hungary: the importance of soil organic matter. Environ Sci Pollut R 22:10800-10810

26. Binnemans K, Pontikes Y, Jones PT et al (2013) Recovery of rare earths from industrial waste residues: a concise review. In: 3rd International Slag Valorisation Symposium: the transition to sustainable materials management, 191-205

27. Borra CR, Pontikes Y, Binnemans K et al (2015) Leaching of rare earths from bauxite residue (red mud). Miner Eng 76:20-27

28. Ju SH, Zhang YF, Zhang Y et al (2011) Clean hydrometallurgical route to recover zinc, silver, lead, copper, cadmium and iron from hazardous jarosite residues produced during zinc hydrometallurgy. J Hazard Mater 192:554-558

29. Li CX, Wei C, Xu HS et al (2012) Recovery of valuable metals from zinc plant residues by two-stage selective atmospheric leaching process. Adv Mater Res 396-398:552-555

30. Nishihama S, Hirai T, Komasawa I (1999) Separation and recovery of gallium and indium from simulated zinc refinery residue by liquid-liquid extraction. Ind Eng Chem Res 38:1032-1039

31. Raghavan R, Mohanan PK, Patnaik SC (1998) Innovative processing technique to produce zinc concentrate from zinc leach residue with simultaneous recovery of lead and silver. Hydrometallurgy 48:225-237

32. Koopman C, Witkamp GJ (2000) Extraction of lanthanides from the phosphoric acid production process to gain a purified gypsum and a valuable lanthanide by-product. Hydrometallurgy 58:51-60

33. Preston JS, Cole PM, Craig WM et al (1996) The recovery of rare earth oxides from a phosphoric acid by-product.1. Leaching of rare earth values and recovery of a mixed rare earth oxide by solvent extraction. Hydrometallurgy 41:1-19

34. Binnemans K, Jones PT, Blanpain B et al (2015) Towards zerowaste valorisation of rare-earth-containing industrial process residues: a critical review. J Clean Prod 99:17-38

35. Blissett RS, Rowson NA (2012) A review of the multi-component utilisation of coal fly ash. Fuel 97:1-23

36. Sommerville R, Blissett R, Rowson N et al (2013) Producing a synthetic zeolite from improved fly ash residue. Int $\mathrm{J}$ Miner Process 124:20-25

37. European Coal Combustion Products Association (2015). http:// www.ecoba.com/index.html. Accessed 2 Dec 2015 
38. Jones MR, Sear LKA, Mccarthy MJ et al (2006) Changes in coal fired power station fly ash: recent experiences and use in concrete. In: Ash Technology Conference, UK Quality Ash Association

39. Yao ZT, Ji XS, Sarker PK et al (2015) A comprehensive review on the applications of coal fly ash. Earth Sci Rev 141:105-121

40. Mattigod SV (2003) Rare earth elements in fly ashes as potential indicators of anthropogenic soil contamination. In: Sajwan KS, Alva AK, Keefer RF (eds) Chemistry of trace elements in fly ash. Springer, New York, pp 155-164

41. Franus W, Wiatros-Motyka MM, Wdowin M (2015) Coal fly ash as a resource for rare earth elements. Environ Sci Pollut R 22:9464-9474

42. Seidel A, Zimmels Y (1998) Mechanism and kinetics of aluminum and iron leaching from coal fly ash by sulfuric acid. Chem Eng Sci 53:3835-3852

43. Dehaine Q, Filippov LO (2015) Rare earth (La, Ce, Nd) and rare metals (Sn, Nb, W) as by-product of kaolin production, Cornwall: Part1: selection and characterisation of the valuable stream. Miner Eng 76:141-153

44. Steer J, Grainger C, Griffiths A et al (2014) Characterisation of BOS steelmaking dust and techniques for reducing zinc contamination. Ironmak Steelmak 41:61-66

45. Kelebek S, Yoruk S, Davis B (2004) Characterization of basic oxygen furnace dust and zinc removal by acid leaching. Miner Eng 17:285-291

46. Havlik T, Kukurugya F, Orac D et al (2012) Acidic leaching of EAF steelmaking dust. World of Metall Erzmetall 65:48-56

47. Jaafar I, Griffiths AJ, Hopkins AC et al (2011) An evaluation of chlorination for the removal of zinc from steelmaking dusts. Miner Eng 24:1028-1030

48. Havlik T, Souza BVE, Bernandes AM et al (2006) Hydrometallurgical processing of carbon steel EAF dust. J Hazard Mater 135:311-318

49. Sofilic T, Rastovcan-Mioc A, Cerjan-Stefanovic S et al (2004) Characterization of steel mill electric-arc furnace dust. J Hazard Mater 109:59-70

50. Bolam SG, Rees HL, Somerfield P et al (2006) Ecological consequences of dredged material disposal in the marine environment: a holistic assessment of activities around the England and Wales coastline. Mar Pollut Bull 52:415-426

51. Akcil A, Erust C, Ozdemiroglu S et al (2015) A review of approaches and techniques used in aquatic contaminated sediments: metal removal and stabilization by chemical and biotechnological processes. J Clean Prod 86:24-36

52. Mulligan CN, Yong RN, Gibbs BF (2001) An evaluation of technologies for the heavy metal remediation of dredged sediments. J Hazard Mater 85:145-163

53. Loser C, Seidel H, Hoffmann P et al (2001) Remediation of heavy metal-contaminated sediments by solid-bed bioleaching. Environ Geol 40:643-650

54. Loser C, Zehnsdorf A, Hoffmann P et al (2006) Bioleaching of heavy metal polluted sediment: influence of sediment properties (Part 2). Eng Life Sci 6:364-371

55. Seidel H, Ondruschka J, Morgenstern P et al (1998) Bioleaching of heavy metals from contaminated aquatic sediments using indigenous sulfur-oxidizing bacteria: a feasibility study. Water Sci Technol 37:387-394

56. Tsai LJ, Yu KC, Chen SF et al (2003) Effect of temperature on removal of heavy metals from contaminated river sediments via bioleaching. Water Res 37:2449-2457

57. Kjeldsen P, Barlaz MA, Rooker AP et al (2002) Present and longterm composition of MSW landfill leachate: a review. Crit Rev Environ Sci Technol 32:297-336

58. Kaartinen T, Sorormunen K, Rintala J (2013) Studies on material composition of closed Finnish landfills-potential for landfill mining? In: 2nd international academic Symposium on enhanced landfill mining, 14-16

59. Quaghebeur M, Laenen B, Geysen D et al (2013) Characterization of landfilled materials: screening of the enhanced landfill mining potential. J Clean Prod 55:72-83

60. Sun B, Zhao FJ, Lombi E et al (2001) Leaching of heavy metals from contaminated soils using EDTA. Environ Pollut 113:111-120

61. Wu Q, Cui YR, Li QL et al (2015) Effective removal of heavy metals from industrial sludge with the aid of a biodegradable chelating ligand GLDA. J Hazard Mater 283:748-754

62. Hong HC, Su C, Jadhav UU (2014) Bioleaching of metals from steel slag by Acidithiobacillus thiooxidans culture supernatant. Chemosphere 117:652-657

63. Cheng Y, Guo ZH, Liu XD et al (2009) The bioleaching feasibility for $\mathrm{Pb} / \mathrm{Zn}$ smelting slag and community characteristics of indigenous moderate-thermophilic bacteria. Bioresour Technol 100:2737-2740

64. Lee JC, Pandey BD (2012) Bio-processing of solid wastes and secondary resources for metal extraction: a review. Waste Manag $32: 3-18$

65. Mackay DM, Cherry JA (1989) Groundwater contamination: pump-and-treat remediation. Environ Sci Technol 23:630-636

66. Jarvis NJ (2007) A review of non-equilibrium water flow and solute transport in soil macropores: principles, controlling factors and consequences for water quality. Eur $\mathrm{J}$ Soil Sci 58:523-546

67. Kahl G, Ingwersen J, Nutniyom P et al (2008) Loss of pesticides from a litchi orchard to an adjacent stream in northern Thailand. Eur J Soil Sci 59:71-81

68. Cote CM, Bristow KL, Ross PJ (2000) Increasing the efficiency of solute leaching: impacts of flow interruption with drainage of the "preferential flow paths". J Contam Hydrol 43:191-209

69. LaGrega MD, Buckingham PL, Evans JC (1994) Hazardous waste management. McGraw-Hill, New York

70. Dwyer BP (1994) Feasibility of permeation grouting for creating subsurface barriers. Sandia National Laboratories SAND94-0786 UC-721, Albuquerque

71. Dennis ML, Turner JP (1998) Hydraulic conductivity of compacted soil treated with biofilm. J Geotech Geoenviron Eng 124:120-127

72. Thullner M, Mauclaire L, Schroth MH et al (2002) Interaction between water flow and spatial distribution of microbial growth in a two-dimensional flow field in saturated porous media. J Contam Hydrol 58:169-189

73. Trefry MG, Rayner JL, Johnston CD (1998) Hydrological measures of success for a pilot bioclogging study at Largs North, South Australia. CSIRO Land and Water

74. Khire JM, Khan MI (1994) Microbially enhanced oil-recovery (MEOR). Part 1. Importance and mechanism of MEOR. Enzyme Microb Technol 16:170-172

75. Chu J, Ivanov V, Stabnikov V et al (2013) Microbial method for construction of an aquaculture pond in sand. Geotechnique 63:871-875

76. Cameselle C, Chirakkara RA, Reddy KR (2013) Electrokineticenhanced phytoremediation of soils: status and opportunities. Chemosphere 93:626-636

77. Cundy AB, Bardos RP, Church A et al (2013) Developing principles of sustainability and stakeholder engagement for "gentle" remediation approaches: the European context. J Environ Manag 129:283-291

78. European Commission (2014) Horizon 2020 - Work Programme 2014-2015. European Commission Decision C 4995

79. Rybicka J, Tiwari A, Leeke GA (2016) Technology readiness level assessment of composites recycling technologies. J Clean Prod 112:1001-1012 
80. Brown LR (2010) Microbial enhanced oil recovery (MEOR). Curr Opin Microbiol 13:316-320

81. Acar YB, Gale RJ, Alshawabkeh AN et al (1995) Electrokinetic remediation: basics and technology status. J Hazard Mater 40:117-137

82. Crane R, Sinnett D, Cleall PJ et al (2016) Physicochemical composition of wastes and co-located landscape designations at legacy mine sites in south west England and Wales: implications for resource potential. Resour Conserv Recycl

83. Liu ZB, Li HX (2015) Metallurgical process for valuable elements recovery from red mud: a review. Hydrometallurgy 155:29-43

84. Agatzini-Leonardou S, Oustadakis P, Tsakiridis PE et al (2008) Titanium leaching from red mud by diluted sulfuric acid at atmospheric pressure. J Hazard Mater 157:579-586

85. Ochsenkuhnpetropulu M, Lyberopulu T, Ochsenkuhn KM et al (1996) Recovery of lanthanides and yttrium from red mud by selective leaching. Anal Chim Acta 319:249-254

86. Qu Y, Lian B (2013) Bioleaching of rare earth and radioactive elements from red mud using Penicillium tricolor RM-10. Bioresour Technol 136:16-23

87. Vachon P, Tyagi RD, Auclair JC et al (1994) Chemical and biological leaching of aluminum from red mud. Environ Sci Technol 28:26-30

88. Raghavan R, Mohanan PK, Swarnkar SR (2000) Hydrometallurgical processing of lead-bearing materials for the recovery of lead and silver as lead concentrate and lead metal. Hydrometallurgy 58:103-116
89. Farahmand F, Moradkhani D, Safarzadeh MS et al (2009) Brine leaching of lead-bearing zinc plant residues: process optimization using orthogonal array design methodology. Hydrometallurgy 95:316-324

90. Habashi $\mathrm{F}$ (1985) The recovery of the lanthanides from phosphate rock. J Chem Technol Biotechnol A 35:5-14

91. Izquierdo M, Querol X (2012) Leaching behaviour of elements from coal combustion fly ash: an overview. Int J Coal Geol 94:54-66

92. Moreno N, Querol X, Ayora C (2001) Utilization of zeolites synthesized from coal fly ash for the purification of acid mine waters. Environ Sci Technol 35:3526-3534

93. Bulaev AG, Muravyov MI, Pivovarova TA et al (2013) Bioprocessing of mining and metallurgical wastes containing non-ferrous and precious metals. Adv Mater Res 825:301-304

94. Mulligan CN, Kamali M, Gibbs BF (2004) Bioleaching of heavy metals from a low-grade mining ore using Aspergillus niger. J Hazard Mater 110:77-84

95. Raza N, Raza W, Zafar WI et al (2016) Beneficiation of zinc from electric arc furnace dust using hydrometallurgical approach. Russ J Appl Chem 89:836-845

96. Zeng XF, Twardowska I, Wei SH et al (2015) Removal of trace metals and improvement of dredged sediment dewaterability by bioleaching combined with Fenton-like reaction. J Hazard Mater 288:51-59

97. Fedje KK, Stromvall AM (2016) Evaluation of solid residues quality after enhanced $\mathrm{Cu}$ leaching of polluted soils. Sci Total Environ 563:676-682 